\title{
Linking long-term landscape dynamics to the multiple interactions among ecosystem services in the European Alps
}

\author{
Lukas Egarter Vigl • Uta Schirpke • \\ Erich Tasser $\cdot$ Ulrike Tappeiner
}

Received: 28 May 2015/ Accepted: 25 February 2016/Published online: 9 May 2016

(C) The Author(s) 2016. This article is published with open access at Springerlink.com

\begin{abstract}
Context Human driven land-use and land-cover change (LULC) is considered to be among the greatest ecological pressures in mountain regions. Over the past century, across the European Alps, extensive LULC changes have been observed, affecting ecosystem goods and services (ESs).

Objectives For eight case study sites across the Alpine arc we aimed to provide a spatiotemporal explicit assessment of the impacts of LULC dynamics on ES provision and interactions, including cultivated crops, plant material, climate regulation, soil erosion control and aesthetics.

Methods We quantified ES provision in biophysical terms at four time periods $(1850,1955,1985,2005)$ using spatially explicit LULC based assessment models. ES interactions were identified by statistically analyzing the spatiotemporal pattern among ES capacities.
\end{abstract}

Electronic supplementary material The online version of this article (doi:10.1007/s10980-016-0389-3) contains supplementary material, which is available to authorized users.

L. Egarter Vigl $(\bowtie) \cdot$ U. Schirpke · E. Tasser .

U. Tappeiner

Institute for Alpine Environment, EURAC Research,

Viale Druso 1, 39100 Bolzano, BZ, Italy

e-mail: lukas.egarter@eurac.edu

L. Egarter Vigl · U. Schirpke · U. Tappeiner Institute of Ecology, University of Innsbruck,

Sternwartestr. 15, 6020 Innsbruck, Austria
Results Over the past century forested areas have increased mainly at the cost of grasslands, while on easily accessible sites and fertile valley floors agricultural intensification occurred. ES provision shifted between 1850 and 2005, from a predominance of production ESs in 1850 to a landscape characterized by regulating ESs in 2005. Spatiotemporal analyses of ES interactions revealed trade-offs between regulating and cultural ESs and within the provisioning ES bundle and allowed to derive three different ES trajectories: regions developing from single to multifunctional sites in terms of service provision, sites reducing their service capacities and sites with rather stationary patterns over broad time periods.

Conclusions We demonstrated that ES capacities in complex agro-ecological mountain regions are highly sensitive to long-term landscape dynamics. We conclude that assessing ES capacities and interactions in an explicitly spatiotemporal manner can help to guide evidence-based environmental measures.

Keywords LULC-change in mountain regions . Multiple ES provision - Synergy and trade-off assessment - Spatiotemporal pattern of ecosystem service (ES) capacities

\section{Introduction}

Agriculturally-managed mountain regions are predominantly perceived as non-profitable and inefficient 
(Grêt-Regamey et al. 2008). They are usually hard to access and lack infrastructure. Nevertheless, they provide a diversity of ecosystem services (ESs) (Lavorel et al. 2011; Briner et al. 2012) for local residents and also for the population in contiguous lowlands. In the European Alps over the past 150 years, a dramatic change in land-use and landcover (Rutherford et al. 2008) leading to changes in mountain ecosystems has been observed. The abandonment of more marginal agricultural areas, in particular, has resulted in more homogenous landscape patterns (Tasser et al. 2007) and in the loss of biodiversity (Chapin et al. 2000; Zimmermann et al. 2010). Although the area of agricultural land has decreased rapidly over the past few decades, agricultural landscapes are still the prevailing Alpine feature (Busch 2006; Tappeiner et al. 2008). They ensure a variety of goods and services, including food and forage provision, natural hazard regulation, the preservation of landscape aesthetics and a considerable contribution to the water and carbon cycle (Millennium Ecosystem Assessment 2005; GrêtRegamey et al. 2008; Elkin et al. 2013).

Human management practices influence the ES potential in landscapes dominated by agriculture (Zhang et al. 2007). Agro-ecosystems for their own part strongly depend on services from natural, unmanaged ecosystems (Power 2010). Thus, optimal landscape management for the conservation of ecosystem functioning is based on an adequate balance between human modifications and naturalness. In managed mountain ecosystems, like the Alps, the complexity of ES provision is high (Grêt-Regamey et al. 2012; Huber et al. 2013), and land that is either marginally or only periodically cultivated may be more sensitive to external impacts than other areas are (Rounsevell et al. 2006; Briner et al. 2013b). Especially because of the diversity in types of terrain and other landscape features, such as land-use classes and local cultural traditions, spatial and temporal dynamics have become a crucial factor in ES provision (Wang et al. 2014). These characteristics, combined with considerable heterogeneity in climate conditions, which range from Mediterranean climates at low elevations in the Southern Alps to cold temperate climates at high elevations in the Central and Northern Alps, have led to the development of a diverse small-scale farming system, which is seen over the entire European Alps (Flury et al. 2013).
The spatial identification, allocation and quantification of ESs in complex environments remains a key research challenge (Reyers et al. 2009; Anton et al. 2010; De Groot et al. 2010; Seppelt et al. 2011), especially in mountain regions where data availability is usually scarce. While some studies, on scales ranging from regional to continental, have been conducted (Chan et al. 2006; Metzger et al. 2006; Egoh et al. 2009; Kienast et al. 2009; Eigenbrod et al. 2010; Schirpke et al. 2013a; Briner et al. 2013b), a comprehensive study at high spatial resolution, analyzing and comparing different types of small-scale agricultural regions, has not been undertaken. Despite the process of ES identification and quantification, there is no comprehensive understanding of the multiple interactions among mountain ESs at different temporal and spatial scales (Rodriguez et al. 2006; Haase et al. 2012). To our knowledge, no one has yet attempted a spatially explicit quantitative assessment of the trade-offs and synergies between multiple ESs related to land-use changes over a long time perspective, using datasets that are representative for large part of the Alpine mountain range.

This paper aims to present a comprehensive assessment of the different spatiotemporal development of selected ESs and their complex interrelationships. On the basis of actual and historical land-use and land-cover (LULC) maps, covering approximately the past 150 years of cultural landscape development, we show the different effects of changing landscape patterns on selected services, including: (a) provisioning services (cultivated crops and plant material); (b) regulating services (climate regulation and soil erosion control); and c) cultural services (aesthetic value). All these services have been previously identified as crucial for managed mountain regions (Lamarque et al. 2011; Lorencová et al. 2013; Briner et al. 2013a). To ensure consideration of dynamic socioeconomic aspects, such as regional cultural characteristics as well as demographic and societal changes, the study area covers eight sites, distributed across four different Alpine countries (Italy, France, Switzerland and Austria) over the entire mountain range. The key aspects of the present analysis can be summarized by the following two questions: I) how do past and current LULC patterns affect the provision of multiple ESs in the Alps, especially from a spatial perspective, and II) how do interactions among multiple ESs behave over a long time period? 


\section{Methods}

Study area

The present study was conducted in eight sites across the European Alps (Table 1). The selection of each site stemmed from work carried out by Tappeiner et al. (2003), which classified the European Alps into eight Agrarian Structure Regions (ASR). Each ASR represents a group of municipalities with common environmental, agro-economic and demographic conditions calculated through a clustering procedure on datasets covering the time period 1980-2000. This process considered both static (30) and dynamic (13) parameters, including natural characteristics like climatic types and topographical conditions, socioeconomical indices like population density and employment rates of different sectors, as well as agricultural indicators like the density of livestock and the economic orientation of farms. For validation purposes, for each ASR at least one representative model region was selected $(>70 \%$ of probability of allocation to a specific ASR) in order to carry out extended investigations aimed at a more complete understanding of the statistically constructed ASR. On the same basis we selected the eight sites for the present study, one for each ASR, together covering approximately $1800 \mathrm{~km}^{2}$ of land in 32 municipalities. The geographical extent of the study area comprises the south-eastern Alps of Italy, the south-western Alps of France and the northern-Alps of Switzerland and Austria.

\section{Data collection}

Calculation of the selected ESs was predominately based on LULC maps representing specific time periods. The maps were generated by on-screen digitizing within an ESRI ArcGIS Desktop environment (ESRI 2014) using georectified aerial images and historical maps, such as the Francisco-Josephinian Cartographical Register (third cartographical register of the Austrian crown-lands) for regions of the former Habsburg Empire, the Siegfried map for Switzerland and the Cadastre Napoléon for France. The average spatial resolution of the digitized maps was approximately 1:20.000. For a detailed description of the LULC delineation and classification method, please refer to the work carried out by Tasser et al. (2009). To account for time differences in the basic cartographic material (i.e., not all historical maps/aerial images were available for exactly the same years), the generated LULC maps were subsequently categorized into four time periods: LULC maps derived from historical maps for the years between 1800 and 1879 were grouped into the 1850 time frame, whereas LULC maps derived from aerial images of the periods between 1950-1961, 1979-1990 and 1998-2010 were grouped into the 1955, 1985 and 2005 time frames, respectively. In addition, we used topographic parameters such as elevation, aspect, slope and visibility, which were derived from a digital elevation model at a spatial resolution of $30 \mathrm{~m} \times 30 \mathrm{~m}$ (http://gdem. ersdac.jspacesystems.or.jp/).

ES assessment approaches

Given the spatiotemporal scale of the present study, we limited our focus to five ESs to qualitatively and quantitatively assess the impacts of LULC change on mountain ecosystems. Provisioning services were represented by cultivated crops and by plant material; regulating services by climate regulation and soil erosion control; and cultural services by aesthetic value. The ES assessment methodology we applied was closely related to the approaches published in Wischmeier and Smith (1978), Egger et al. (2004), Tappeiner et al. (2008), and Schirpke et al. (2013a, b). The CICES 4.3 terminology was used for ES classification. Figure 1 gives an overview of the conceptual ES assessment framework.

\section{Cultivated crops}

To make cultivated crop production (indicator: annual and permanent corps) comparable over a 150-yearlong time period, a standardized unit had to be developed that accounts for changes in the national currencies, monetary de- or inflation and improvements in productivity. Hence, we estimated the annual and permanent crop production (ES Crops) on the basis of the number of man hours $\left(h \mathrm{ha}^{-1}\right)$ needed to acquire the basic commodities produced in one hectare of a specific crop category. Man hours were obtained from the ratio between the sum of consumer prices $C P$ ( $€ \mathrm{ha}^{-1}$, Fig. 2b) of different agricultural commodities and the average hourly salary $H R\left(€ \mathrm{~h}^{-1}\right.$, Fig. 2a) of an unskilled laborer. The following equation summarizes 
Table 1 Basic characteristics of the ASR and the respective study areas

\begin{tabular}{|c|c|c|c|c|}
\hline $\begin{array}{l}\text { ASR } \\
\text { Type }\end{array}$ & $\begin{array}{l}\text { ASR } \\
\text { description }\end{array}$ & $\begin{array}{l}\text { Study area } \\
\text { name and size }\end{array}$ & $\begin{array}{l}\text { Elevation } \\
\text { range-climate } \\
\text { conditions }\end{array}$ & ASR classification and location of the respective study sites \\
\hline (1) & $\begin{array}{l}\text { High labor, } \\
\text { intensive } \\
\text { crop region }\end{array}$ & $\begin{array}{l}\text { Unterland } \\
\text { (I)- } \\
120 \mathrm{~km}^{2}\end{array}$ & $\begin{array}{l}\text { 200-1900 m } \\
\text { Warm } \\
\text { temperate, } \\
\text { humid }\end{array}$ & 8 \\
\hline (2) & $\begin{array}{l}\text { Labor- } \\
\text { extensive } \\
\text { arable land } \\
\text { region }\end{array}$ & $\begin{array}{l}\text { Alpes-de- } \\
\text { Haute- } \\
\text { Provence } \\
\text { (F)- } \\
107 \mathrm{~km}^{2}\end{array}$ & $\begin{array}{l}500-900 \mathrm{~m} \\
\text { Humid with } \\
\text { Mediterranean } \\
\text { influence }\end{array}$ & 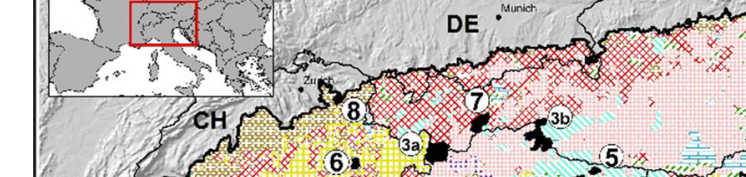 \\
\hline (3) & $\begin{array}{l}\text { Grassland } \\
\text { region }\end{array}$ & $\begin{array}{l}\text { a Vinschgau } \\
\text { (I)- }- \\
460 \mathrm{~km}^{2} \\
\text { b Pustertal } \\
\text { (I)- } \\
480 \mathrm{~km}^{2}\end{array}$ & $\begin{array}{l}\text { 900-3700 m } \\
\text { Semi-humid, } \\
\text { with cold } \\
\text { season }\end{array}$ & 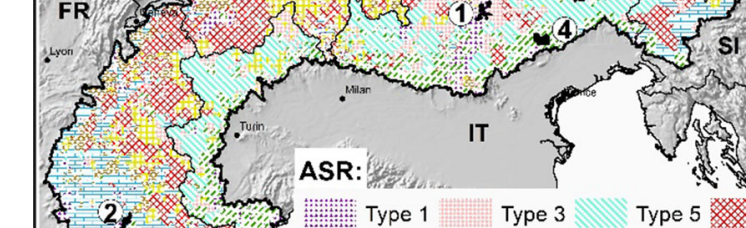 \\
\hline (4) & $\begin{array}{l}\text { Small-scale } \\
\text { grassland } \\
\text { farms }\end{array}$ & $\begin{array}{l}\text { Piave }(\mathrm{I})- \\
155 \mathrm{~km}^{2}\end{array}$ & $\begin{array}{l}\text { 200-1600 m } \\
\text { Warm } \\
\text { temperate, } \\
\text { humid }\end{array}$ & 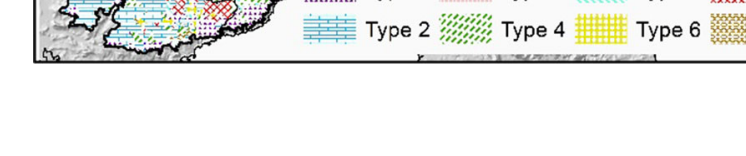 \\
\hline (5) & $\begin{array}{l}\text { High farmland } \\
\text { abandonment }\end{array}$ & $\begin{array}{c}\text { Carnia (I)- } \\
114 \mathrm{~km}^{2}\end{array}$ & $\begin{array}{l}500-2500 \mathrm{~m} \\
\text { Humid with cold } \\
\text { season }\end{array}$ & \\
\hline (6) & $\begin{array}{l}\text { Structured, } \\
\text { full-time } \\
\text { farming }\end{array}$ & $\begin{array}{l}\text { Graubünden } \\
\qquad \begin{array}{l}(\mathrm{CH})- \\
70 \mathrm{~km}^{2}\end{array}\end{array}$ & $\begin{array}{l}\text { 1100-3000 m } \\
\text { Semi-humid } \\
\text { with cold } \\
\text { season }\end{array}$ & \\
\hline (7) & $\begin{array}{l}\text { Alpine } \\
\text { standard } \\
\text { region }\end{array}$ & $\begin{array}{l}\text { Stubaitaltal } \\
\text { (A)- } \\
265 \mathrm{~km}^{2}\end{array}$ & $\begin{array}{l}600-3500 \mathrm{~m} \\
\text { Humid with cold } \\
\text { season }\end{array}$ & \\
\hline (8) & $\begin{array}{l}\text { Large-scale } \\
\text { cattle } \\
\text { breeding } \\
\text { Study sites: } \\
\text { Alps: }\end{array}$ & $\begin{array}{l}\text { Toggenburg } \\
\quad(\mathrm{CH})- \\
71 \mathrm{~km}^{2} \\
1842 \mathrm{~km}^{2} \\
181,000 \mathrm{~km}^{2}\end{array}$ & $\begin{array}{l}600-1300 \mathrm{~m} \\
\text { Humid with cold } \\
\text { season }\end{array}$ & \\
\hline
\end{tabular}

the applied procedure for a given time period and crop category (annual or permanent crops):

$E S \_C r o p s_{y}=\frac{\sum C P_{y}}{\overline{\mathrm{x}}_{H R_{y}}}$

The derived nonmonetary unit considers both the development of the productivity of a specific crop category in terms of CP (Schneider 1967; Engel 1970; Klose and Jungmann-Stadler 2006; Pies 2008) and the temporal changes in the purchasing power reflected by HR (Mattes 1929; Rauser 1980; Trapp 1999; Klose and Jungmann-Stadler 2006; Pies 2008) (Table 2). The data inputs for the analysis were obtained from multiple sources, including an extensive literature review, data from national statistical institutes and records from the historic chronicles of the Hapsburg Monarchy and the Bavarian Empire. Especially for the early time periods, nationwide mean values for each parameter (i.e., hourly salary) had to be used, depending primarily on the data availability. All records first had to be standardized (i.e., for currency homogeneity) and rescaled for comparability. 


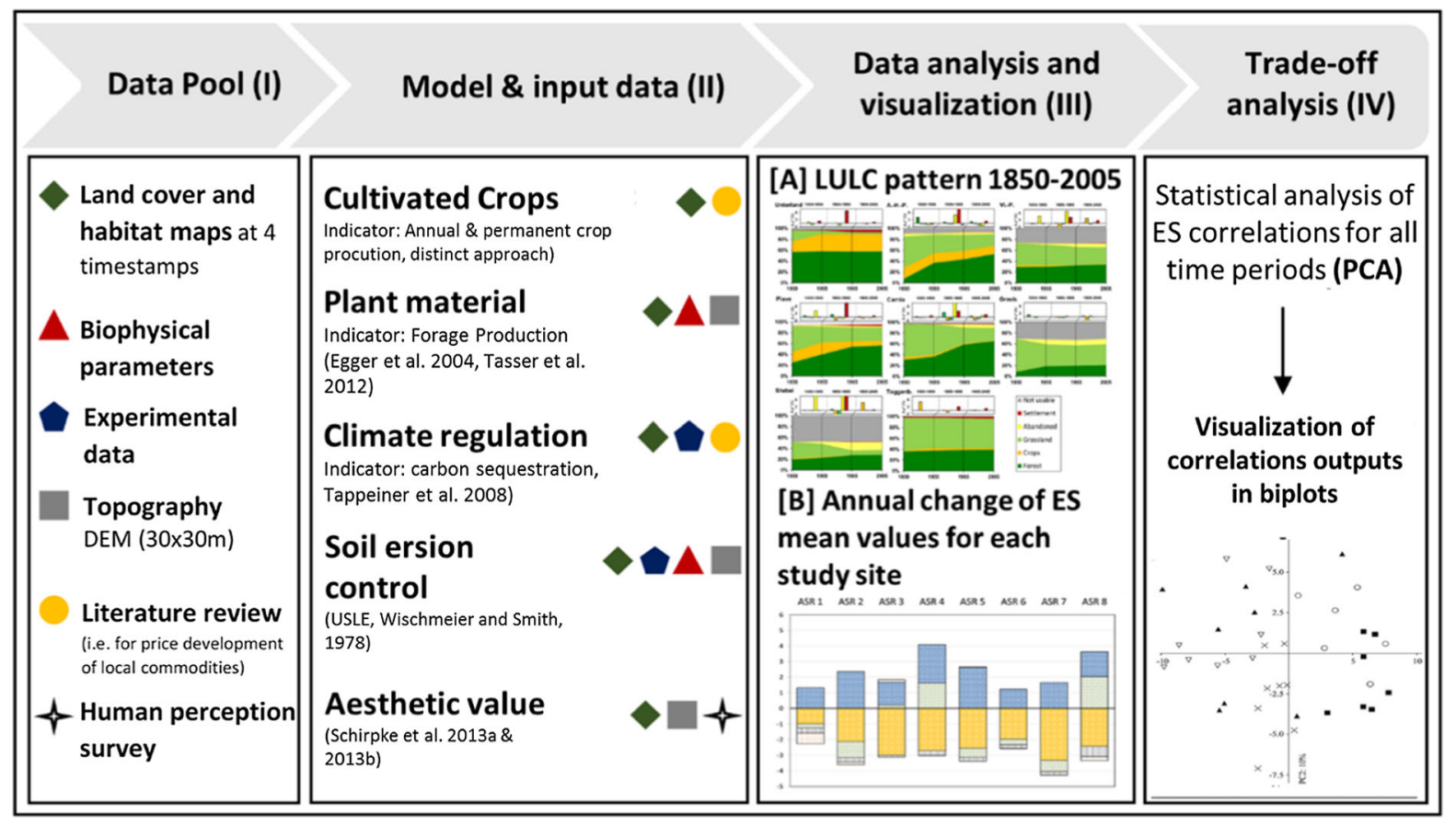

Fig. 1 Conceptual framework of the IV-step ES assessment approach applied for this study: I collection of base datasets, II ES model approach with associated datasets, III analyses of
LULC pattern between 1850 and 2005 and evaluation of ES changes between time periods and, $I V$ statistical analyses (PCA) of synergies and trade-offs
Fig. 2 a Development of the hourly cross salary. b Consumer price development of products cultivated in 1 ha of land, annual and permanent crops listed separately
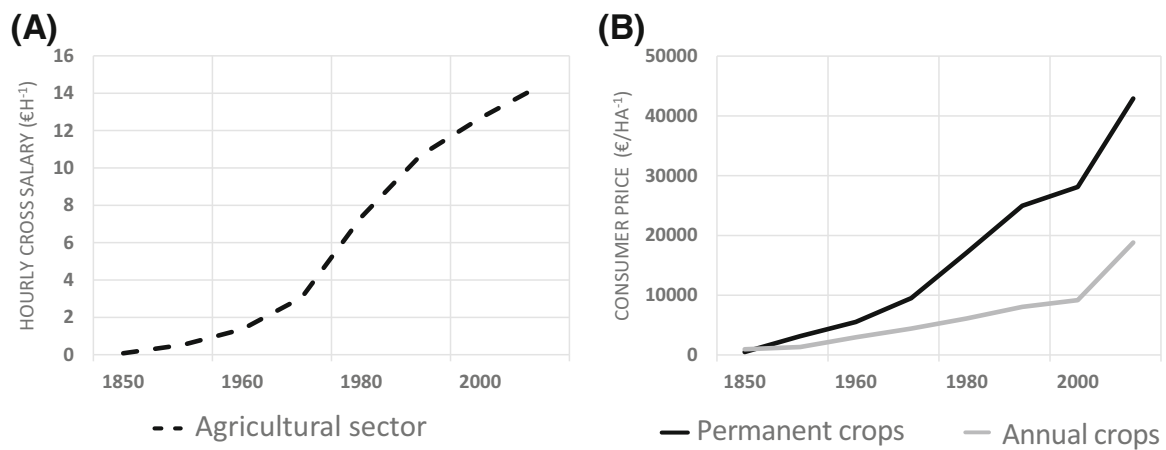

Plant material

We estimated the plant material ES (indicator: forage quantity) on the basis of the productivity of different types of permanent grasslands (Egger et al. 2004, Tasser et al. 2012). The approach considered the length of the growing season, derived as a function of elevation and climate conditions (Harflinger and
Table 2 Working hours necessary for an unskilled laborer to buy the products from 1 ha of arable land at different time periods

\begin{tabular}{lrrrr}
\hline & 1850 & 1955 & 1985 & 2005 \\
\hline Permanent crops (h) & 6203 & 5992 & 2328 & 2981 \\
Annual crops (h) & 11835 & 2546 & 829 & 1307 \\
\hline
\end{tabular}

Permanent and annual crops are listed separately 
Knees 1999), a topographical correction factor that depend on slope and aspect and the amount of summer mean precipitation. To better account for changes in the abandoned land category, we standardized the forage production ESs to the extent of agricultural land in 1850 for all study sites.

\section{Climate regulation}

We assessed climate regulation ESs (indicator: carbon sequestration) by assigning to each land cover type the carbon pool ( $\mathrm{Mg} \mathrm{C} \mathrm{ha}{ }^{-1}$ ) according to aboveground and belowground phytomass $\left(\mathrm{Mg} \mathrm{ha}^{-1}\right)$ and $\mathrm{C}$-stock $\left(\mathrm{g} \mathrm{g}^{-1}\right)$. The relevant datasets were derived from a literature review and our own measurements (Tappeiner et al. 2008; Schirpke et al. 2013a). For the carbon stocks of forests, we additionally considered the biomass density change at the different time periods (Patek 2013).

\section{Soil erosion control}

To estimate the soil erosion control service we used the Universal Soil Loss Equation (USLE; Wischmeier and Smith 1978), using root density $\left(\mathrm{km} / \mathrm{m}^{2}\right)$ for the stability factor, slope for the topographic factor and mean vegetation cover of the specific land cover types for the management factors (Schirpke et al. 2013a). Mean vegetation cover and root density were derived from our own measurements (Tasser et al. 2005; Tappeiner et al. 2008), and slope was calculated from the digital elevation model (ASTER Project).

\section{Aesthetic value}

The aesthetic value of a landscape was assessed based on the assumption that a mosaic of different land uses obtain a higher appreciation than a more homogenous landscape. This approach is grounded on the different human perception theories, like the prospect-refugee and savannah theory (Appleton 1975; Orians 1980, respectively) and is presented in different studies (Hunziker et al. 2007; Kienast 2014) and environments. For this study, we combined a questionnairebased photo survey, a viewshed analysis (from DEM) and a landscape diversity indicator to assess the potential aesthetic value (Schirpke et al. 2013a). The photo questionnaire relied on an empirical survey by Schirpke et al. 2013b, who asked tourists to give preference scores to a series of pictures of Alpine landscapes. The resulting preference values were then linked to the different LULC categories, revealing landscape elements that receive higher appreciations than others. The viewshed analysis was based on a digital elevation model at a resolution of $30 \mathrm{~m} \times 30 \mathrm{~m}$, with observer points regularly distributed over the entire study area at a distance of $300 \mathrm{~m}$ from each other. To obtain the visible land cover, we intersected the viewsheds with the corresponding LULC datasets (Schirpke et al. 2013b). To account for the spatial characteristics of the mosaicked Alpine landscape, we calculated the landscape diversity index using the FRAGSTATS software package (McGarigal et al. 2012). Finally, all three components were weighted equally and summed up into one value.

Data analysis and ES interactions

For all ESs, we calculated the area weighted mean values per hectare on a pixel-by-pixel basis (cell size $30 \mathrm{~m}$ ). Subsequently, to visualize the spatiotemporal behavior of ESs within our study sites, we first calculated the percentage change from one timeframe to the next (i.e., 1985-2005) for each study site, relative to a starting point of zero.

Lastly, we ran a principal component analysis (PCA) for the entire dataset for all time periods in order to assess ES interactions over time (Maes et al. 2011; García-Nieto et al. 2013) in terms of trade-offs and synergies. Based on the correlation rate and distribution we defined a trade-off as the simultaneous increase of one ES and the reduction of another service in the same time period or location (Rodriguez et al. 2006). Conversely, we referred to synergy when two ESs are correlated in the same direction of the PCA space. The performed analyses projects the spatiotemporal data for each location into a two-dimensional coordinate plane (components F1 and F2). The Kaiser criterion (i.e., eigenvalue $>1$ ) was used to select the principal components, that account for most of the variance of the measures of the ES supply. Due to the skewed distribution of the dataset, we applied a log transformation $(\ln (\mathrm{x}+1))$ on $\mathrm{ES}$ mean values before running the PCA. All the statistical analyses were performed using the software package Canoco 5.0 (www.canoco5.com).

Variables, in the present study ES types, are represented as arrows and indicate in which direction 
of the PCA space the ES value reach its maximum. Samples, in our case the 8 ASR study sites in the 4 different time periods, are presented as colored points on the graph and receive each two coordinates (one for F1 and one for F2). The final biplot of the factor loadings allow the visualization of both, ES interactions in terms of synergies and trade-offs and the movement of ES provision, at a study site scale, through time. ESs, that load on opposite position of the PCA axes spatially exclude one another (trade-off), those loading in the same direction of a specific axes can be obtained in synergy. Moreover it is possible to identify in which directions of the PCA space the sites moved throughout time in terms of ES provision.

\section{Results}

We first describe the general land-use changes and summarize then the major results of the ES assessment process observed across our study sites. Second, we analyze the temporal ES interactions, focusing on synergies and trade-off among services. For further details on the explicit spatial and temporal changes of LULC and ESs in each region, please refer to Online Appendix 1 (Table A1) and Online Appendix 2 (Table A2), respectively.

Landscape development and ESs change between 1850 and 2005

In line with other studies, the results from the eight study sites confirm that forested areas have increased over the past 150 years mainly at the cost of pastures and meadows (Fig. 3). With the exception of two regions (Stubai (A) and Toggenburg $(\mathrm{CH})$ ), forests today represent the prevailing landscape feature. Unfavorable locations, such as high alpine meadows and steep slopes, have been abandoned first and are slowly reverting to unmanaged forests, thus, leading to a more homogenous landscape. On the fertile valley bottoms and on easily accessible locations on hillsides, in general, agricultural intensification processes could be observed. Today, fruit and crop cultivation dominate the landscapes at lower elevations (i.e., Unterland (I) and A.-H.-P. (F)), while on productive areas at higher elevation meadows and pastures are common. Moreover, an ongoing increment in the settlement area throughout all study sites could be observed $\left(\varnothing+2.75 \%\right.$ year $\left.^{-1}\right)$.

The greatest LULC changes, however, occurred in the years between 1955 and 1985. On inconveniently situated locations on hillsides, agricultural fields were increasingly being taken out of cultivation $\left(\varnothing-1.1 \%\right.$ year $\left.^{-1}\right)$ and large parts of former managed areas were abandoned $\left(\varnothing+5.75 \%\right.$ year $\left.^{-1}\right)$. The period between 1985 and 2005 was characterized by a slowing down of the observed trends: in particular, urban settlements and abandoned land expanded less rapidly $\left(\varnothing+0.9\right.$ and $\varnothing+0.2 \%$ year $^{-1}$, respectively). The time period 1850-1955, although it spanned over 100 years, was characterized by only minor variations in LULC (up to $\pm 0.2 \%$ year $^{-1}$ ). The only consistent exception can be found in the abandoned land-use category, which showed an overall increase of $\left(\varnothing+2.5 \%\right.$ year $\left.^{-1}\right)$ even over this early time period.

These human-driven shifts in LULC, strongly related to land management strategies, also affected important ESs.

\section{Cultivated crops}

The annual and permanent crop production ES strongly reflected the socio-economic transformation that occurred in Alps over the past century, as it was based on productivity levels and consumer price indices from the agricultural sector. As expected, the crop production ES in the Alps decreased continuously over time, reaching its low in the 1980s. Since then, however, it has maintained a stable level. An exception to this widely observed trend can be found in regions where large areas of annual crops have been preserved as an important landscape feature over the entire study period, mainly favored by topographical conditions that have allowed an intensification in the management process. Examples can be found in the Département Alpes-de-Haute-Provence in the southeast of France and in the Piave region in the Southern Alps of Italy both showing considerable increase in crop production of up to $+3.5 \%$ year $^{-1}$ for the period 1985-2005. A slightly different development, which also led to an increased crop production ESs, could be detected in different location in fertile valley bottoms (i.e., Adige Valley, Italy), where the LULC transition process included a change from annual crops or grasslands to permanent crops (i.e., from grain fields to 

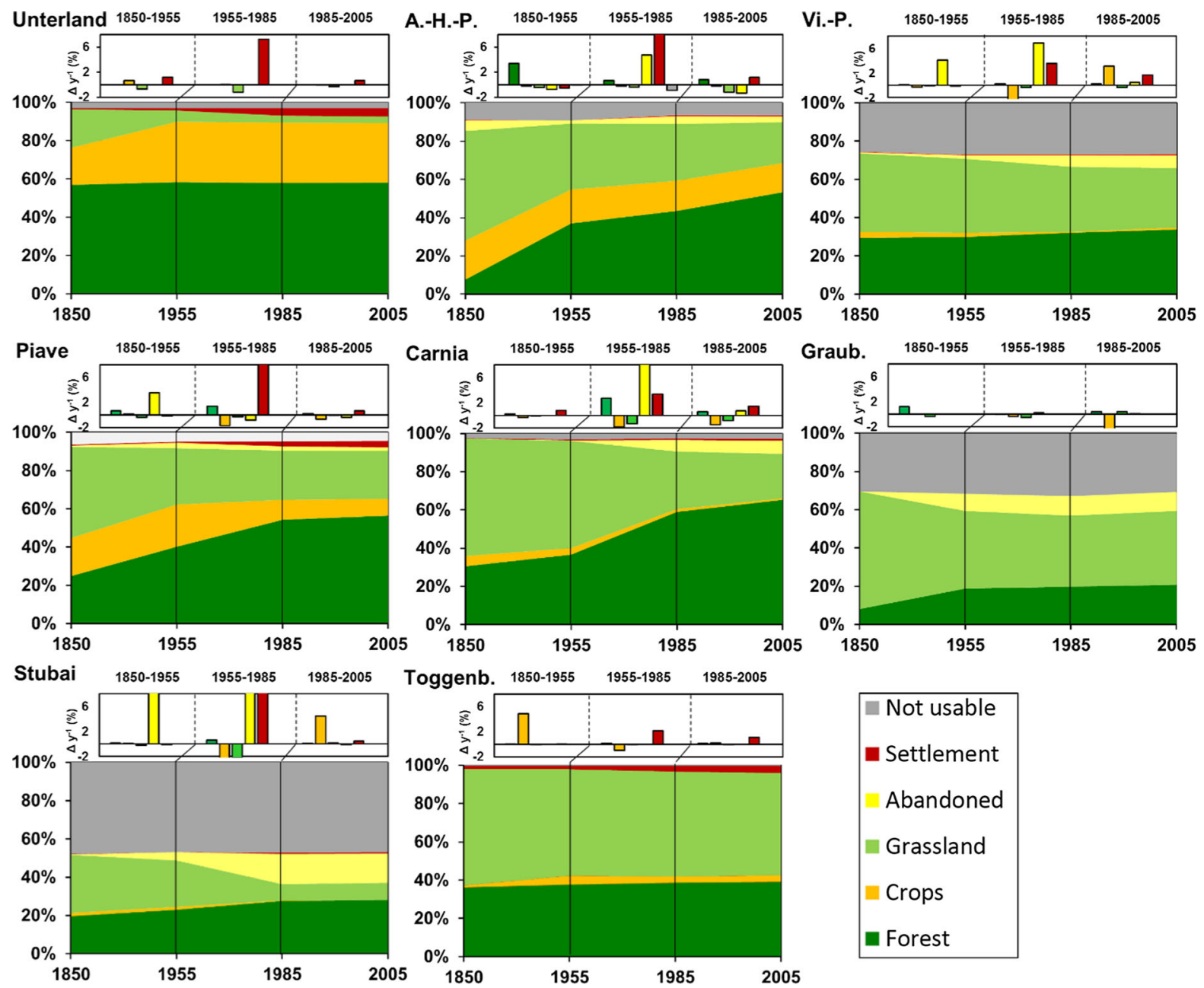

Fig. 3 Historical LULC developments in the eight study sites across the European Alps: (1) the intensive crop region of Unterland (I), (2) the extensive arable land region of A.-H.-P. (F), (3) the South-Tyrolean grassland region of Vi.-P. (I), (4) the small scale grassland farm region of Piave (I), (5) the retraction

apple orchards or vineyards). The generally favorable market conditions for these crop types, especially over the past decades, and the positive cost and productivity trends in this agricultural subsector have resulted in an increasing ES provision, especially over the past two decades.

\section{Plant material}

Forage production ES was highest in meadows with a high land-use intensity on low elevations and large summer precipitation. For our study sites, these parameters applied best to Piave (I) and Toggenburg region of Carnia (I), (6) the full-time farming region of Graubünden $(\mathrm{CH})$, (7) the alpine region of Stubai (A) and (8) the large-scale cattle breeding region of Toggenburg $(\mathrm{CH})$. Small diagrams indicate annual changes between time periods (1850-1955, 1955-1985 and 1985-2005). (Color figure online)

$(\mathrm{CH})$. The latter one for example, in contrast to most of the other analyzed regions, could maintain a high mean fodder production between the 1850s and 2005. This result reflected the prevailing grassland and livestockbased farming systems, which were characterized by agricultural intensification in the most favorable locations. We found that regions with a high or increasing crop production ES had a low or a decreasing forage production ES (i.e., Unterland (I), A.-H.-P. (F) and Carnia (I)). This once more reflects the widely observed land-use conversion process, which included the abandonment of grasslands or the conversion of meadows into more profitable crop yields. 
Climate regulation

As expected, we found the greatest carbon stocks in regions that were affected by extensive land abandonment processes and large forest regrowth. The Carnia region in the north-eastern Italian Alps, for example, is characterized by meadows with very low land-use intensities and a large share of forests. Between 1850 and 2005 we could observe an increase of forests of $+250 \%$ compared to the initial stage in 1850 . During the same time period the carbon stocks, however, increase by nearly 4 times. In general, our results indicate a continuous increase of carbon stocks over the study period, which is strongly correlated with the densification of forested areas and boosted by the Alpine-wide land-use transition from grasslands and annual crops to abandoned land and eventually back to forests. Substantially lower stocks were only found in high-altitude regions of the central Alps, dominated by extensive grasslands and pastures or bare soils (Graubünden $(\mathrm{CH})$ and Stubai $(\mathrm{A})$ ).

\section{Soil erosion control}

In nature, protection against soil erosion, along with climate, mainly depends on topography (slope angle) and LULC (root density and plant cover). Low intensity meadows and pastures in general have a higher root density than forests. In turn, forested areas have a better vegetation cover (Tasser et al. 2005). Hence, the less vulnerable areas were located in regions with low slope gradient and a high degree of permanent plant cover and root density. Lowlands in the main Alpine valleys and the Alpine foothills (Unterland (I), Piave (I) and Carnia (I)) met these criteria best. In general, our results indicate a continuous increase in ES potential throughout the entire study area and the different time periods. This can be explained both by a massive increase in forests at the expense of intensively used grasslands on mountainsides and by a decreasing fraction of agricultural land in fertile lowlands.

Aesthetic value

The most aesthetically attractive regions were those characterized by open landscapes and dominated by a mosaic of forests, meadows and pastures of low landuse intensity. The least attractive were homogenous landscapes featuring large forests, fruit plantations and intensively managed grasslands. In the Alps, high mountain ranges like the Stubai Alps, which were characterized by mixed scenery and long views, typically met these criteria best (i.e., Stubai (A)). For the entire period covered by this study, the aesthetic value increased all over the Alps, primarily owing to the abandonment of agricultural land. This is furthermore confirmed by the fact that in regions where carbon sequestration was low to moderate, the aesthetic value was rather high (i.e., Vi.-P. (I) and Piave (I)). However, in five out of eight study sites, the forest regeneration, occurred between 1985 and 2005, is reflected by a stagnant aesthetic value in recent decades.

Relationship between ESs: Trade-offs and synergies over space and time

We assessed the trade-offs and synergies between ES types and study sites among different timeframes by applying a PCA. We reduced the five ES-variables for all four time periods to two dimensions in which the selected components (Factor 1 and Factor 2) accounted for most of the total variance $(97.9 \%)$. The biplot for Factor 1 and Factor 2 are shown in Fig. 4.

The variance in the data reveal clear pattern of relationships among ES capacities, both, at a spatial and a temporal level and reflect the major observed LULC transition periods. The first PCA axis (F1), is characterized by a spatial allocation among regulating services: climate regulation (carbon sequestration) and soil erosion control are positively correlated to each other. Study sites (i.e., Carnia) that provide these services are dominated by forests and land categories with a high degree of plant cover and root density. On the same axis, in opposite direction, we find spatially dislocated study sites. They are correlated towards aesthetic value and thus, trading-off against those locations characterized by regulated services (i.e., A.H.-P.). Extended forested regions are usually seen as more homogenous landscape features and hence, often perceived as less attractive then mixed structured landscapes. The second axis of the PCA (F2) is marked by study sites that are significantly correlated towards provisioning services, either towards cultivated crops (i.e., Unterland, positively) or towards plant material (i.e., Toggenburg, negatively). Thus, the factor 


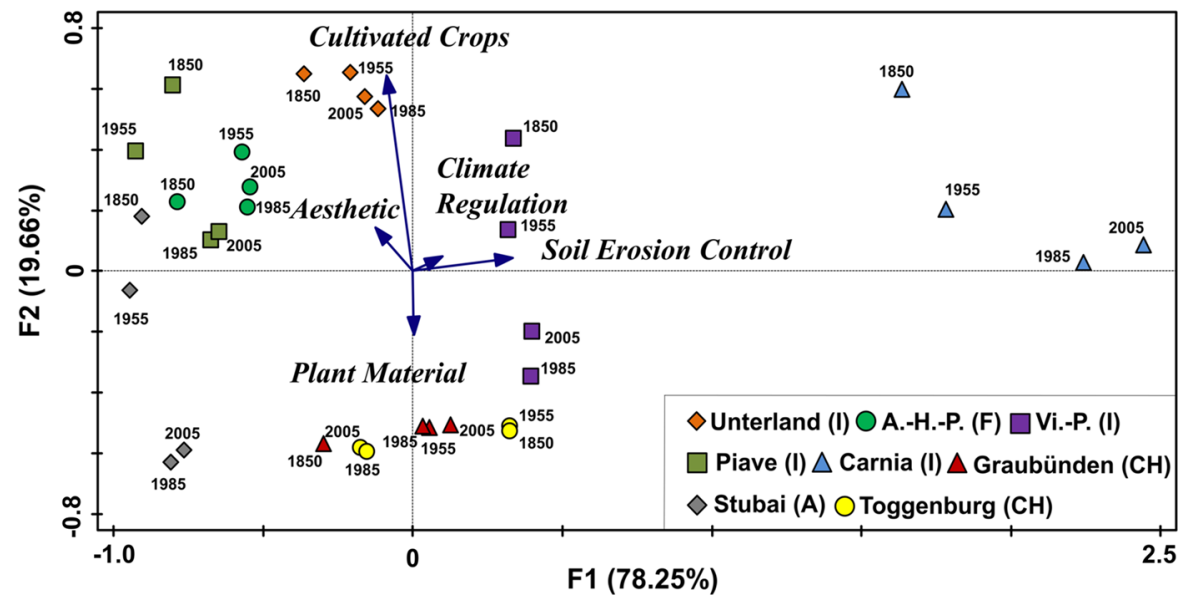

Fig. 4 Biplot of the principal component analysis (PCA) illustrating the spatiotemporal relationships (trade-offs and synergies) between different ES types (vectors) and specific study sites (symbols). The length of the vectors represents the degree of the factor loadings, the longer, the stronger and the angle between the vectors the correlation among them. The $x$ -

loadings indicate a spatial dislocation among sites dominated by cultivated crops and plant material: management strategies and natural topographic conditions favored the specialization of agricultural sectors in specific geographic regions, which in turn results in the opposite factor loadings found in the PCA. Furthermore, we could identify synergetic effects between aesthetic supply and cultivated crops potential, expressed in a high correlation between sites developing on that axis. General agricultural intensification occurred in the scarce valley floors of the Alps, usually embedded in a mosaic of different land uses and thus, corroborating the link between landscape composition and scenic appreciation.

Focusing on ES relationships in terms of service capacities throughout time, we could detected different trajectories for the specific case study sites. In our project, ES trajectories are driven by long-term LULC transitions that include mostly agricultural land or succession stages thereof, as well as forested land. While some sites (i.e., Vi.-P. (I), Carnia (I), Stubai (A)) revealed large variations in ES supply as illustrated through their movements in the PCA space, other sites showed rather stationary signals (Unterland (I), A.-H.-P. (F)). Overall we could differentiate between three spatial patterns: Regions that developed form a mainly single service dominated site in 1850 to a multi-functional site in 2005 (Stubai (A), Vi.-P. (I)); axis (F1) is characterized by a trade-off between regulating services (loading in a positive direction) and cultural services (loading in a negative direction), while the $y$-axis (F2) is characterized by a trade-off within the provisioning services type (plant material is negatively correlated to cultivated crops)

sites that had an opposite development and reduced their ES capacities (Piave (I), Carnia (I)) and sites with rather stationary pattern over time, with no or only minor changes in the provisioning capacities (Unterland (I), Toggenburg (CH)).

\section{Discussion}

In the present study we draw on the well-established links among LULC and ES provision to explore their changes in a mountain landscape over broad time periods (Briner et al. 2013a; Bateman et al. 2013; Lawler et al. 2014; Balthazar et al. 2015). Our results indicate that differences in the underlying drivers of LULC change, such as changes in the prevailing land management regime, can have lasting impacts on ES supply. We find that the provision of ESs throughout the study sites shifted between 1850 and 2005, from a predominance of production ESs in a mainly agricultural landscape in 1850 to a landscape characterized by regulating ESs in 2005. This development was strongly influenced by a bidirectional process, which took place simultaneously: land-use intensification by different anthropogenic processes (i.e., industrialization) and land abandonment due to a reduction or shift in agriculture activities (Monteiro et al. 2011). 
On the basis of our historic LULC maps, we identified two main land use transition periods that directly influenced ES provision and followed the global shifts in land management regimes at European level (Jepsen et al. 2015). The first broad trend can be observed in the 1950s, when traditional mixed crop and livestock farming systems were either progressively converted into mechanized and specialized livestock farming systems through intensification or eventually abandoned because farmers took up alternative professions (Strijker 2005). This happened because of the response of producers to changes in consumption habits and market requirements (Mazoyer and Roudart 1999), which made mixed farming often unprofitable. Such land-use conversions also altered landscape composition and functioning, both of which directly affect the provision of ESs (Jiang et al. 2013; Lorencová et al. 2013; Lawler et al. 2014). We found evidences that provisioning services, mainly annual and permanent crops, generally decreased during this first broad transition period, whereas regulating services increased (Fig. 5b). This is further supported by the complex topographical conditions in the Alps and by natural ongoing biophysical changes. Abandonment processes occurred first on the highest and steepest parcels whereas initial uses rarely changed on the lowest and flattest sites. Land abandonment, however, often was accompanied by specialization and intensification processes (Gellrich et al. 2007; Zimmermann et al. 2010) at low elevations, thus mitigating the overall impacts of the different drivers on ES provision at the case study level.

A second LULC transition occurred mainly in the mid-1980s and was characterized by a re-intensification of agricultural production, especially in meadows in favorable locations and in annual and permanent crops in the fertile valley bottoms. The main drivers were agro-environmental policies that promoted intensive farming practices and the liberalization of markets (Kristensen et al. 2004; Jepsen et al. 2015), although these did not result in a re-opening of formerly abandoned areas (Pech et al. 1999). Provisioning services in general, but especially the production of annual and permanent crops, increased over almost the entire Alpine mountain range (Fig. 5c). This process accompanied positive global market developments in the crop sector (Monteiro et al. 2011). Examples can be found in the favored locations of inner-alpine dry valleys, like the Unterland and Rhône valley, where an area-wide specialization in vine and fruit cultivation occurred during this period. Nevertheless, the second LULC transition was characterized by a strong increase in regulating services (especially climate regulation and soil erosion control) due to an ongoing land use shift out of agricultural land into forests due to natural reforestation. This also aligns with our findings on landscape aesthetics (aesthetic value). We find that the shift to more homogenous landscape patterns, such as extensive forest and larger urban areas, is considered less attractive; this is furthermore confirmed by the associated results of the landscape metrics analysis (Schirpke et al. 2013b).

In line with other studies (Mottet et al. 2006; Gellrich et al. 2007; Huber et al. 2014; Balthazar et al. 2015), our results show that ES provision in the Alps is not only directly influenced by LULC change, biophysical conditions and topography, but also by the interactions between these drivers. These complex dynamics also make it likely that ES associations are not stationary in space and time and are further confirmed by our statistical analyses (PCA). In terms

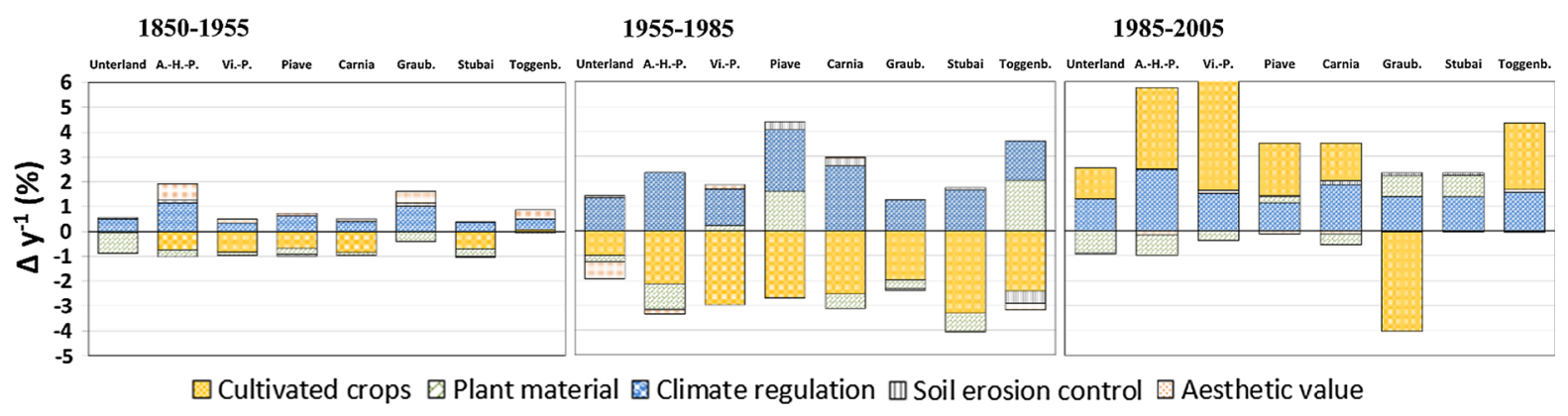

Fig. 5 Annual change of ES mean values for each study site (1850-1955, 1955-1985 and 1985-2005) relative to a starting point of zero. A positive value $(>0)$ indicates an increase in the ES supply, a negative value $(<0)$ a decrease. (Color figure online) 
of spatial trade-offs and synergies among different study sites we could positively test correlations within regulating ESs (between climate regulation and soil erosion control), as both services directly benefit from the observed increase in forested areas. Over the same time period we also detected clear trade-offs (negative correlations) occurring among different groups of services: aesthetic value showed trade-offs with regulating services as well as cultivated crops with plant material (forage quantity). Both results are linked to the ongoing shift out of agricultural land (grasslands and pastures) into forests and urban settlements. In contrast, we found no statistically significant evidence of a spatial correlation between provisioning services and regulation services over the study period. However, especially trade-offs with regulating services are of crucial importance, as they are usually at core of different services types (cultural and provisioning) and are considered an integral part for the resilience of ecosystems (Rodriguez et al. 2006). ES capacities valid at one time period (i.e., 1850 ), eventually may move towards the provision of another service type in the successive period (i.e., 1955), thus complicating their management. Hence, the spatial and temporal explicit knowledge where interactions occur is a crucial information that allows to build ES trajectories according to the specific patterns.

In our study we were able to evidence three different ES trajectories over the entire 150-year (1850-2005) period evaluated, ranging from sites that magnified their ES capacities to locations that reduced ES provision over time. This is most likely attributable to the complex socio-ecological dynamics and land management schemes in the Alps that caused ES relationships to vary over such a long time period and in the different locations (Mouchet et al. 2014; Huber et al. 2014). The widely observed LULC changes towards a more forested landscape, however, positively influenced ES associations by increasing the multi-functionality of the different study sites to provide ESs. This is in line with Raudsepp-Hearne et al. (2010), who was able to correlate multifunctional landscapes with higher capacity levels of regulating services. Regions with high regulating capacities have better prospective for future development in terms of services diversification, because this service types are at the bases of different provisioning services. In general, the simplified landscape produced by ES trajectories captured the most important spatial structures of past and current LULC dynamics. They correspond to the main ecological and land management specific pattern of the different case study sites and corroborate the link between agro-ecological forces and ES interactions. Study sites known to have rather stationary land-use dynamics, i.e., for cultivated crops, where grouped together also in our trade-off analyses. Hence, a deep understanding of such agroecological forces may allow also to predict more accurately ES interactions in terms of trade-offs and synergies through time and should be considered in further studies at different scales and environments.

\section{Methodological considerations}

The assessment of the impact of LULC dynamics on multiple ES provision in mountain regions is a challenging task, especially when taking into consideration 8 different study sites, owing to specific socioeconomic, environmental and topographic conditions. The assessment of these impacts inevitably involves the simplification of complex landscape processes and, hence can introduce bias (Lorencová et al. 2013).

In our study we decided to stratify the Alpine mountain range according to Tappeiner et al. 2003 into eight ASR and to select one representative study site for each region in order to carry out extended investigations. As the stratification process was mainly based on data records representative for the years 1980-2000, we had to account for the specific limitations of this approach in terms of validity over the entire period evaluation (1850-2005). We considered this aspect, however, to be of minor significance for this study, as the changes in the major drivers of ES provision (i.e., changes in land-use regimes) occurred to a greater extent in the more recent decades (Jepsen et al. 2015).

To cover the temporal scale of approximately 150 years, we needed to combine different data types from multiple sources that were not always available for exactly the same time period. This involved specific limitations that had to be taken into consideration when using this data for ES assessment (Holland et al. 2011). Our study was primarily based on historical LULC datasets split up into four time periods. Each LULC map for example provides only a snapshot of the landscape at a certain point in time. Landscape dynamics occurring between these points 
are not considered. Clearly, important market and biophysical forces that influence ES provision, including shifts in societal preferences, soil properties and climate change, could not be addressed in this study (Bürgi et al. 2015). A full analysis of the potential impacts of landscape dynamics on ES provision is beyond the scope of this study, as basic data to support an analysis of a long time line for the different study sites is mostly missing. We focused on the identification of study site specific ES trend developments rather than an exact quantification in biophysical terms. We based our analysis on five ESs that we considered representative and crucial for mountain environments and thus sufficient for the purpose of the present study.

Lastly, there are many possible factors that can alter ES interaction analysis. Synergies and trade-off are often influenced by socio-ecological feedbacks that are hardly tangible or by economic and legal incompatibilities that exclude certain ES interaction (i.e., through environmental laws). Hence, further ES research should also consider the changes in these interdependencies in the context of ES assessment.

\section{Conclusion}

Spatiotemporal explicit ES assessments, as we propose in this study, are important instruments to further understand the complex interactions between landscape composition, topographical conditions and ES capacities. We found clear indications that changes in land management regimes directly influence ES provision in the European Alps, especially regarding regulating and provisioning ESs. We demonstrate that ES interactions in terms of synergies and trade-offs occur between all services types, but differ in magnitude and between specific spatial and temporal scales. Our result show that in general the observed LULC changes towards a more forested landscape, lead to a greater diversity in ES provision and that ES provision can be enhanced by appropriate land management practices.

We expect that the spatial and temporal trajectories of ES interactions that we found in our eight case study site are similar to those in other mountain landscapes. Given the spatial and temporal dimension of our study, the proposed framework could be the basis for similar studies in different environments as it perfectly meets the EU biodiversity strategy on ES assessments at different temporal and spatial scales.

More generally, our research demonstrates that it is meaningful to analyze long-term LULC changes in complex environments in order to gather more explicit knowledge of the multiple interactions of ES provision. Future land-use policies in mountain regions should take into consideration the importance of ES interactions, for both the social and ecological forces, and support specific promotion campaigns for farmers and land managers. Even on a small scale, great differences between supplies of ESs can be found, making spatially and temporally explicit ES analysis essential to support environmental decision making at the national and transnational level.

Acknowledgments We wish to thank three anonymous reviewers for their contribution to improve the manuscript. This research was partly funded by the BiodivERsA project REGARDS, the FWF Austrian Science Fund (I 1056-B25), the European Territorial Cooperation Program Interreg IV ItalyAustria, the Autonomous Province of Bozen/Bolzano - South Tyrol and the Office of the Government of Tyrol ("KuLaWi" project, CUP B26D09000010007). Open access funding provided by University of Innsbruck and Medical University of Innsbruck.

Open Access This article is distributed under the terms of the Creative Commons Attribution 4.0 International License (http:// creativecommons.org/licenses/by/4.0/), which permits unrestricted use, distribution, and reproduction in any medium, provided you give appropriate credit to the original author(s) and the source, provide a link to the Creative Commons license, and indicate if changes were made.

\section{References}

Anton C, Young J, Harrison P, Musche M, Bela G, Feld C, Harrington R, Haslett J, Pataki G, Rounsevell MA, Skourtos M, Sousa JP, Sykes M, Tinch R, Vandewalle M, Watt A, Settele J (2010) Research needs for incorporating the ecosystem service approach into EU biodiversity conservation policy. Biodivers Conserv 19:2979-2994

Appleton J (1975) The experience of landscape, 2nd revised edn, 1995. Wiley, New York

ASTER GDEM Version 2 (2011) http://www.jspacesystems.or. jp/ersdac/GDEM/E/4.html.

Balthazar V, Vanacker V, Molina A, Lambin EF (2015) Impacts of forest cover change on ecosystem services in high Andean mountains. Ecol Ind 48:63-75

Bateman IJ, Harwood AR, Mace GM, Watson RT, Abson DJ, Andrews B, Binner A, Crowe A, Day BH, Dugdale S, Fezzi C, Foden J, Hadley D, Haines-Young R, Hulme M, Kontoleon A, Lovett AA, Munday P, Pascual U, Paterson J, Perino G, Sen A, Siriwardena G, van Soest D, Termansen 
M (2013) Bringing ecosystem services into economic decision-making: land use in the United Kingdom. Science 341:45-50

Briner S, Elkin C, Huber R (2013a) Evaluating the relative impact of climate and economic changes on forest and agricultural ecosystem services in mountain regions. J Environ Manag 129:414-422

Briner S, Elkin C, Huber R, Gret-Regamey A (2012) Assessing the impacts of economic and climate changes on land-use in mountain regions: a spatial dynamic modeling approach. Agric Ecosyst Environ 149:50-63

Briner S, Huber R, Bebi P, Elkin C, Schmatz DR, Gret-Regamey A (2013b) Trade-offs between ecosystem services in a mountain region. Ecol Soc 18(3):35

Bürgi M, Silbernagel J, Wu J, Kienast F (2015) Linking ecosystem services with landscape history. Landsc Ecol $30: 11-20$

Busch G (2006) Future European agricultural landscapesWhat can we learn from existing quantitative land use scenario studies? Agric Ecosyst Environ 114:121-140

Chan KMA, Shaw MR, Cameron DR, Underwood EC, Daily GC (2006) Conservation planning for ecosystem services. PLoS Biol 4:e379

Chapin FS III, Zavaleta ES, Eviner VT, Naylor RL, Vitousek PM, Reynolds HL, Hooper DU, Lavorel S, Sala OE, Hobbie SE, Mack MC, Diaz S (2000) Consequences of changing biodiversity. Nature 405:234-242

de Groot RS, Alkemade R, Braat L, Hein L, Willemen L (2010) Challenges in integrating the concept of ecosystem services and values in landscape planning, management and decision making. Ecol Complex 7:260-272

Egger G, Angermann K, Aigner S, Buchgraber K (2004) GISgestützte Ertragsmodellierung zur Optimierung des Weidemanagements auf Almweiden. Heft 40:79 S

Egoh B, Reyers B, Rouget M, Bode M, Richardson DM (2009) Spatial congruence between biodiversity and ecosystem services in South Africa. Biol Conserv 142:553-562

Eigenbrod F, Armsworth PR, Anderson BJ, Heinemeyer A, Gillings S, Roy DB, Thomas CD, Gaston KJ (2010) The impact of proxy-based methods on mapping the distribution of ecosystem services. J Appl Ecol 47:377-385

Elkin C, Gutierrez AG, Leuzinger S, Manusch C, Temperli C, Rasche L, Bugmann H (2013) A $2{ }^{\circ} \mathrm{C}$ warmer world is not safe for ecosystem services in the European Alps. Glob Chang Biol 19:1827-1840

Engel F (1970) Tabellen alter Münzen, Maße und Gewichte: zm Gerauch für Archivbenutzer. Bösendahl

ESRI (Environmental Systems Research Institute) (2014) ArcMap 10.2. ESRI, Redlands, California

Flury C, Huber R, Tasser E (2013) Future of mountain agriculture in the Alps. In: Mann S (ed) The future of mountain agriculture. Springer, Heidelberg, pp 105-126

García-Nieto AP, García-Llorente M, Iniesta-Arandia I, MartinLopez B (2013) Mapping forest ecosystem services: from providing units to beneficiaries. Ecosyst Serv 4:126-138

Gellrich M, Baur P, Koch B, Zimmermann NE (2007) Agricultural land abandonment and natural forest re-growth in the Swiss mountains: a spatially explicit economic analysis. Agric Ecosyst Environ 118:93-108

Grêt-Regamey A, Brunner SH, Kienast F (2012) Mountain ecosystem services: who cares? Mt Res Dev 32:S23-S34
Grêt-Regamey A, Bebi P, Bishop ID, Schmid WA (2008) Linking GIS-based models to value ecosystem services in an Alpine region. J Environ Manag 89:197-208

Haase D, Schwarz N, Strohbach M, Kroll F, Seppelt R (2012) Synergies, trade-offs, and losses of ecosystem services in urban regions: an integrated multiscale framework applied to the Leipzig-Halle Region, Germany. Ecol Soc 17

Harflinger O, Knees G (1999) Klimahandbuch der österreichischen Bodenschätzung. Universitätsverlag Wagner Innsbruck, Wien

Holland R, Eigenbrod F, Armsworth P, Anderson B, Thomas C, Gaston K (2011) The influence of temporal variation on relationships between ecosystem services. Biodivers Conserv 20:3285-3294

Huber R, Briner S, Bugmann H, Elkin C, Hirschi C, Seidl R, Snell R, Rigling A (2014) Inter- and transdisciplinary perspective on the integration of ecological processes into ecosystem services analysis in a mountain region. Ecol Processes 3-9

Huber R, Rigling A, Bebi P, Brand FS, Briner S, Buttler A, Elkin C, Gillet F, Grêt-Regamey A, Hirschi C, Lischke H, Scholz RW, Seidl R, Spiegelberger T, Walz A, Zimmermann W, Bugmann H (2013) Sustainable land use in mountain regions under global change: synthesis across scales and disciplines. Ecol Soc. 18

Hunziker M, Buchecker M, Hartig T (2007) Space and placetwo aspects of the human-landscape relationship. In: Kienast F, Wildi O, Ghosh S (eds) Springer, Netherlands, pp 47-62

Jepsen MR, Kuemmerle T, Müller D, Erb K, Verburg PH, Haberl H, Vesterager JP, Andrič M, Antrop M, Austrheim G, Björn I, Bondeau A, Bürgi M, Bryson J, Caspar G, Cassar LF, Conrad E, Chromý P, Daugirdas V, Van Eetvelde V, Elena-Rosselló R, Gimmi U, Izakovicova Z, Jančák V, Jansson U, Kladnik D, Kozak J, Konkoly-Gyuró E, Krausmann F, Mander Ü, McDonagh J, Pärn J, Niedertscheider M, Nikodemus O, Ostapowicz K, PérezSoba M, Pinto-Correia T, Ribokas G, Rounsevell M, Schistou D, Schmit C, Terkenli TS, Tretvik AM, Trzepacz P, Vadineanu A, Walz A, Zhllima E, Reenberg A (2015) Transitions in European land-management regimes between 1800 and 2010. Land Use Policy 49:53-64

Jiang M, Bullock JM, Hooftman DAP (2013) Mapping ecosystem service and biodiversity changes over 70 years in a rural English county. J Appl Ecol 50:841-850

Kienast F (2014) Landscape-increasingly important for environmental decision. GAIA 23:294-296

Kienast F, Bolliger J, Potschin M, de Groot R, Verburg P, Heller I, Wascher D, Haines-Young R (2009) Assessing landscape functions with broad-scale environmental data: insights gained from a prototype development for Europe. Environ Manag 44:1099-1120

Klose D, Jungmann-Stadler F (2006) Königlich Bayerisches Geld - Zahlungsmittel und Finanzen im Konigreich Bayern 1806-1918. Staatliche Münzsammlung, München

Kristensen LS, Thenail C, Kristensen SP (2004) Landscape changes in agrarian landscapes in the 1990s: the interaction between farmers and the farmed landscape: a case study from Jutland. Denmark J Environ Manag 71:231-244

Lamarque P, Tappeiner U, Turner C, Steinbacher M, Bardgett R, Szukics U, Schermer M, Lavorel S (2011) Stakeholder 
perceptions of grassland ecosystem services in relation to knowledge on soil fertility and biodiversity. Reg Environ Chang 11:791-804

Lavorel S, Grigulis K, Lamarque P, Colace M, Garden D, Girel J, Pellet G, Douzet R (2011) Using plant functional traits to understand the landscape distribution of multiple ecosystem services. J Ecol 99:135-147

Lawler JJ, Lewis DJ, Nelson E, Plantinga AJ, Polasky S, Withey JC, Helmers DP, Martinuzzi S, Pennington D, Radeloff VC (2014) Projected land-use change impacts on ecosystem services in the United States. Proc Natl Acad Sci 111:7492-7497

Lorencová E, Frélichová J, Nelson E, Vačkař D (2013) Past and future impacts of land use and climate change on agricultural ecosystem services in the Czech Republic. Land Use Policy 33:183-194

Maes J, Paracchini ML, Zulian G (2011) A European assessment of the provision of ecosystem services-Towards an atlas of ecosystem services. JRC scientific and technical reports. Publications Office of the European Union, Luxembourg

Mattes W (1929) Oehringer Heimatbuch. Verlag Hohenlohesche Buchhandlung Ferdinand Rau. Öhringen

Mazoyer M, Roudart L (1999) Histoire des agricultures du monde : Du néolithique à la crise contemporaine. Points Histoire

McGarigal K, Cushman S, Ene E (2012) FRAGSTATS v4: spatial pattern analysis program for categorical and continuous maps. computer software program produced by the authors at the University of Massachusetts, Amherst. http:// www.umass.edu/landeco/research/fragstats/fragstats.html.

Metzger MJ, Rounsevell MDA, Acosta-Michlik L, Leemans R, Schroter D (2006) The vulnerability of ecosystem services to land use change. Agric Ecosyst Environ 114:69-85

Millennium ecosystem assessment (2005) Ecosystems and human well-being: synthesis. Island Press, Washington D. C

Monteiro AT, Fava F, Hiltbrunner E, Della Marianna G, Bocchi S (2011) Assessment of land cover changes and spatial drivers behind loss of permanent meadows in the lowlands of Italian Alps. Landsc Urban Plan 100:287-294

Mottet A, Ladet S, Coque N, Gibon A (2006) Agricultural landuse change and its drivers in mountain landscapes: a case study in the Pyrenees. Agric Ecosyst Environ 114:296-310

Mouchet MA, Lamarque P, Martin-Lopez B, Crouzat E, Gos P, Byczek C, Lavorel S (2014) An interdisciplinary methodological guide for quantifying associations between ecosystem services. Global Environ Chang 28:298-308

Orians GH (1980) Habitat selection: General theory and applications to human behavior

Lockard JS (ed.) The evolution of human social behavior. New York, Elsevier. pp 49-66

Patek M (2013) Waldentwicklung und Biomassenveränderung in Neustift im Stubaital in Tirol seit 1834. Master thesis, University of Vienna (A)

Pech M, Mitteault F, Couvreur M (1999) Les mesures agrienvironnementales mises en oeuvre en France [Règlement européen 2078/92 Éléments de bilan ]. Écon rurale 249:6-10

Pies E (2000) Löhne und Preise von 1300 bis 2000. Abhängigkeit und Entwicklung über 7 Jahrhunderte. Verlag E. \& U, Brockhaus, Wuppertal

Power AG (2010) Ecosystem services and agriculture: tradeoffs and synergies. Philos Trans R Soc Lond B 365:2959-2971
Raudsepp-Hearne C, Peterson GD, Bennett EM (2010) Ecosystem service bundles for analyzing tradeoffs in diverse landscapes. Proc Natl Acad Sci 107:5242-5247

Rauser JH (1980) Waldenburger Heimatbuch. Aus der Ortsgeschichte von Waldenburg und Obersteinbach / Sailach 4

Reyers B, O'Farrell PJ, Cowling RM, Egoh BN, Le Maitre DC, Vlok JHJ (2009) Ecosystem services, land-cover change, and stakeholders: finding a sustainable foothold for a semiarid biodiversity hotspot. Ecol Soc 14(1)

Rodriguez JP, Beard TD, Bennett EM, Cumming GS, Cork SJ, Agard J, Dobson AP, Peterson GD (2006) Tradeoffs across space, time, and ecosystem services. Ecol Soc 11:28

Rounsevell MDA, Berry PM, Harrison PA (2006) Future environmental change impacts on rural land use and biodiversity: a synthesis of the ACCELERATES project. Environ Sci Policy 9:93-100

Rutherford GN, Bebi P, Edwards PJ, Zimmermann NE (2008) Assessing land-use statistics to model land cover change in a mountainous landscape in the European Alps. Ecol Model 212:460-471

Schirpke U, Leitinger G, Tasser E, Schermer M, Steinbacher M, Tappeiner U (2013) Multiple ecosystem services of a changing Alpine landscape: past, present and future. Int $\mathbf{J}$ Biodiv Sci Ecosyst Serv Manag 9:123-135

Schirpke U, Tasser E, Tappeiner U (2013) Predicting scenic beauty of mountain regions. Landsc Urban Plan 111:1-12

Schneider L (1967) Der Arbeiterhaushalt im 18. und 19. Jahrhundert

Seppelt R, Dormann CF, Eppink FV, Lautenbach S, Schmidt S (2011) A quantitative review of ecosystem service studies: approaches, shortcomings and the road ahead. J Appl Ecol 48:630-636

Strijker D (2005) Marginal lands in Europe-causes of decline. Basic Appl Ecol 6:99-106

Tappeiner U, Tappeiner G, Hilbert A, Mattanovich E (2003) The EU Agricultural Policy and the environment evalutaion of the Alpine Region. Blackwell, Berlin

Tappeiner U, Tasser E, Leitinger G, Cernusca A, Tappeiner G (2008) Effects of historical and likely future scenarios of land use on above- and belowground vegetation carbon stocks of an Alpine Valley. Ecosystems 11:1383-1400

Tasser E, Schermer M, Siegl G, Tappeiner U (2012) Wir Landschaftsmacher. Vom Seinund Werden der Kulturlandschaft in Nord-, Ost- und Sudtirol. Athesia Buch GmhH, Bozen

Tasser E, Ruffini F, Tappeiner U (2009) An integrative approach for analysing landscape dynamics in diverse cultivated and natural mountain areas. Landsc Ecol 24:611-628

Tasser E, Tappeiner U, Cernusca A (2005) Ecological effects of land-use changes in the European Alps. In: Huber U, Bugmann HM, Reasoner M (Eds.) Springer, Netherlands, pp 409-420

Tasser E, Walde J, Tappeiner U, Teutsch A, Noggler W (2007) Land-use changes and natural reforestation in the Eastern Central Alps. Agric Ecosyst Environ 118:115-129

Trapp W (1999) Kleines Handbuch der Munzkunde und des Geldwesens in Deutschland. Reclamverlag, Stuttgart

Wang W, Guo H, Chuai X, Dai C, Lai L, Zhang M (2014) The impact of land use change on the temporospatial variations of ecosystems services value in China and an optimized land use solution. Environ Sci Policy 44:62-72 
Wischmeier WH, Smith DD (1978) Predicting rainfall erosion losses. A guide to conservation planning, USDA Agricultural handbook. p 537

Zhang W, Ricketts TH, Kremen C, Carney K, Swinton SM (2007) Ecosystem services and dis-services to agriculture. Ecol Econ 64:253-260
Zimmermann P, Tasser E, Leitinger G, Tappeiner U (2010) Effects of land-use and landcover pattern on landscapescale biodiversity in the European Alps. Agric Ecosyst Environ 139:13-22 